\title{
Various Soil Types, Organic Fertilizers and Doses with Growth and Yields of Stevia rebaudiana Bertoni $M$.
}

\author{
Dian Pratama Putra Saragih ${ }^{1 *}$, Azwar Ma'as ${ }^{2}$, Soepriyanto Notohadisuwarno ${ }^{2}$ \\ ${ }^{1}$ Faculty of Agriculture, Universitas Gadjah Mada, \\ ${ }^{2}$ Department of Soil Science, Faculty of Agriculture, Universitas Gadjah Mada \\ Jl. Flora, Bulaksumur, Depok, Sleman, Yogyakarta 55281 \\ *Corresponding email: dianswn93@gmail.com
}

Received: 09 $9^{\text {th }}$ February 2018; Revised: $26^{\text {th }}$ September 2018; Accepted: $12^{\text {nd }}$ December 2018

\begin{abstract}
Stevia has several advantages including the level of sweetness that reaches 100-200\% the sweetness of sugar cane and low calorie so that it is safe to be consumed by diabetics and obesity. The possibilities of plants to grow on different soil properties and fertility become an important issue in agricultural cultivation systems. The treatment of organic fertilizers is increasing the results in agricultural research. The experiments were arranged in Completely Randomized Design (CRD) with 3 various soil types of treatment factors: Alfisol (Al), Andisol (An) and Vertisol (Ve) soil with 2 types of organic fertilizer ie Compost (K) and Manure (SK) and 3 kinds of doses 20 ton ha (12 $^{-1}$ g/pot), 40 ton ha ${ }^{-1}$ (24 $\mathrm{g} / \mathrm{pot}$ ) and 60 ton $\mathrm{ha}^{-1}(36 \mathrm{~g} / \mathrm{pot})$. Data were analyzed using variance analysis (ANOVA) at $\alpha=5 \%$. The results showed that the soil type of Vertisol given by compost fertilizer at 40 ton ha-1 $(24 \mathrm{~g} / \mathrm{pot})$ gave the highest yield on all agronomic parameters, i.e. number of leaves, number of clumps, plant length, dry weight and wet weight. The result showed that stevia at lowland could produce higher yield on vertisol 2.7 ton ha $^{-1}$, alfisol 1 ton ha ${ }^{-1}$ and andisol 0.4 ton ha-1 than the others' whereas in highland the yield was only 0.3 ton ha $\mathrm{a}^{-1}$ (standard fertilizers) but with increasing amounts of biomass of stevia leaves could increase stevioside levels significantly.
\end{abstract}

Keywords: Doses of fertilizer, soil Type, Stevia rebaudiana Bertoni M, stevia yields, type of fertilizer.

\section{INTRODUCTION}

People in Indonesia generally only recognize sugarcane and doub palm as sugar-producing plants. The other plants used as a sweetener that is Stevia. Stevia is more popular in South America, and also in East Asia such as Japan, China and South Korea. In Paraguay, the Guarani Indians have been using stevia as a sweetener for hundreds of years.

The sweetness of stevia was reported to be over 200-300 times that of sucrose sugar. Some research investigated the effect of $\mathrm{K}$ or $\mathrm{P}$ applied to growth and development of Stevia rebaudiana Bertoni. There was no report about application organic manure Stevia cultivation. On the other hand, people are paying more attention to food quality and ecology environment.

The maximum stevioside content at the 40-60 days after planting, with plant height $40-60 \mathrm{~cm}$, and at the flowering stadium. Stevia plant growth requires a number of nutrients in the soil. Soil fertility with good nutrient management can produce optimum for stevia plant that grows on land with low fertility and productivity levels needs to be improved by fertilization (Smarrt, 1992).

Organic matter is a natural resource consisting of all the organic components in the soil that are essential for determining soil fertility. The organic components include live clusters (micro-utilities and flora), freshly decomposed materials and a relatively stable humic material to the microorganism reshuffle. The labile organic material is composed of easily distended materials and is the main source of nutrients (especially $\mathrm{N}$ ) and quickly disappears from the soil (sugar, cellulose and hemicellulose). The stable part generally consists of lignin accumulated in the soil due to slow decomposition process (Ma'as, 1996).

Stevia can grow in almost all types of soil as long as it gets enough water to reach a plant height of 
about one meter (Shock, 1982). In sub-tropical regions, stevia is cultivated as an annual plant. Stevia plants grow in areas with temperatures between $9-43^{\circ} \mathrm{C}$ (Todd, 2010). This plant cannot stand cold temperatures and will not grow in areas with temperatures below $9^{\circ} \mathrm{C}$. The optimal temperature for fast growth is 20 $24^{\circ} \mathrm{C}$ (Singh and Rao, 2005). However, this plant is in dire need of water availability, because the stems and leaves will easily wither if they do not get enough water. Sufficient water availability is a limiting factor for stevia to be able to grow and reproduce high (Lemus-Mondaca et al., 2012).

This study aimed to know the effect of various soil types and organic manure doses of vegetative growth, yields, stevioside levels in Stevia rebaudiana Bertoni.

\section{MATERIALS AND METHODS}

The experiment was conducted from May to August 2017 at Greenhouse of Soil Laboratory, Soil Chemistry and Soil Fertility Laboratory, Faculty of Agriculture, Gadjah Mada University, Yogyakarta. The treatment were assigned in Completely Randomized Design (CRD) with 3 factor. The first factor was type of soil, the second factor was type of organic fertilizers and types of dose.

The materials that used in this study were: 25 days old stevia seedlings from Tawangmangu that grown in the pot with $30 \mathrm{~cm}$ diameters, $19 \mathrm{~cm}$ height with \pm 7 $\mathrm{kg}$ media, three kinds of soil from three different areas were: Alfisol/Al (from Gunung Kidul), Vertisol/Ve (from Mulo village and Pleyen village) and Andisol/An(from Tawangmangu are Nglurah village). The organic fertilizer consisted of compost
(K) (litter of leaves, bran, husks, charcoal and cow dung) and manure (SK) (feces from cow and goat composite mixture) with variation of dose that were 12 $\mathrm{g} /$ pot $(20$ ton ha-1 $), 24 \mathrm{~g} /$ pot $\left(40\right.$ ton ha $\left.{ }^{-1}\right), 36 \mathrm{~g} /$ pot (60 ton ha ${ }^{-1}$ ), and the standard fertilizer NPK Phonska (15-15-15) with $0.1 \mathrm{~g} /$ pot.

Activities undertaken in this study include preparing a greenhouse and planting media, planting stevia plants, maintaining plant (watering every morning $250 \mathrm{ml} /$ pot), harvesting, observing and collecting of data. Observation and data collection were done on the leaves yield, number of clumps, wet weight and dry weight of the harvest with 4 months old. Data were analyzed by variance with Completely Randomized Design (CRD) and Duncan's multiple-range test with $\alpha=5 \%$ error rate.

\section{RESULT AND DISCUSSION}

Alfisol is a relatively recent formed soil which means it still contains many primary minerals that easily decay, crystalline clay mineral, and rich in nutrients. This land has a high base saturation, CEC and high nutrient reserves. Alfisol is a land where there is clay accumulation in the lower horizon; clay buried in the lower horizon is derived from the horizon above and washed down with the movement of water percolation (Hardjowigeno 1993).

Alfisol located in the village of Mulo, Gunungkidul districts became a mean of growing hardwood trees and is on the topography of the ramp then colored with reddish brown. The result of laboratory analysis of alfisol showed that it has 3 soil fractions indicating that the sandy clay loam soil with the most dominant sand fraction is $55 \%, 19 \%$ dust and $26 \%$ clay.

Table 1. Soil analysis

\begin{tabular}{|c|c|c|c|c|c|c|c|}
\hline \multirow{2}{*}{ No. } & \multirow{2}{*}{ Parameters } & \multicolumn{6}{|c|}{ Soil Types } \\
\hline & & \multicolumn{2}{|c|}{ Alfisol } & \multicolumn{2}{|c|}{ Andisol } & \multicolumn{2}{|c|}{ Vertisol } \\
\hline \multirow[t]{4}{*}{1} & Texture & Sandy & ay loam & Sandy loam & & Clay & \\
\hline & *Sand $(\%)$ & 55 & - & 57 & - & 21 & - \\
\hline & *Loam (\%) & 19 & - & 38 & - & 8 & - \\
\hline & ${ }^{*}$ Clay $(\%)$ & 26 & - & 5 & - & 71 & - \\
\hline 2 & Bulk Density $\left(\mathrm{g} \mathrm{cm}^{-3}\right)$ & 1.12 & - & 0.82 & - & 1.36 & - \\
\hline 3 & $\mathrm{pH}$ & 7.55 & Alkaline & 6.94 & Neutral & 7.76 & Alkaline \\
\hline 4 & $\mathrm{CEC}\left(\mathrm{cmol}(+) \mathrm{kg}^{-1}\right)$ & 27.48 & High & 26.89 & High & 47.79 & Very High \\
\hline 5 & Total N (\%) & 0.23 & Low & 0.51 & High & 0.36 & Medium \\
\hline 6 & Available P (mg kg-1) & 3,73 & Very Low & 9.88 & Very Low & 29.38 & Medium \\
\hline 7 & Available K (cmol (+) $\left.\mathrm{kg}^{-1}\right)$ & 0,81 & High & 1.20 & Very High & 0.86 & High \\
\hline 8 & $\mathrm{C}$ - Organic (\%) & 0,80 & Very Low & 3.04 & High & 1.78 & Low \\
\hline 9 & Soil Organic Matter (\%) & 1,38 & Low & 5.23 & High & 3.07 & Medium \\
\hline
\end{tabular}

*Scoring by Puslittan (2005) 
Table 2. Organic fertilizers analysis.

\begin{tabular}{llrr}
\hline \multirow{2}{*}{ No. } & \multirow{2}{*}{ Parameters } & \multicolumn{2}{c}{ Kind of Fertilizers } \\
\cline { 3 - 4 } & & Compost & Manure \\
\hline 1 & $\mathrm{pH}$ & 7.18 & 9.2 \\
2 & C-Organic (\%) & 26.64 & 15.42 \\
3 & CEC $(\mathrm{cmol}(+) / \mathrm{kg})$ & 76.29 & 41 \\
4 & Total N (\%) & 1.44 & 2.11 \\
5 & Total P $(\%)$ & 2.37 & 0.35 \\
6 & Total K (\%) & 3.03 & 0.79 \\
7 & C/N Ratio & 18.5 & 7.3 \\
\hline
\end{tabular}

According to Hanafiah (2014) sand-dominated soils will have macro (large) pores (called more porous), dustdominated soils will have meso (moderately porous) pores, whereas clay-dominated ones will have many pores micro pores (small) or not porous. Therefore, the poreus of the soil will be more easily rooted to penetrate, as well as easier for water and air to circulate (drainage and aeration both with water and air available to plants). However, it will be easier for water to disappear from the soil and vice versa. Observations on pots occupied by alfisol showed water loss 3-4 hours after $250 \mathrm{ml} /$ pot watering in the morning, indicating that alfisol has a rapid infiltration rate.

Andisol contained in the village of Nglurah, Tawangmangu district is a place of vegetable cultivation including stevia, ramps topography with light brown color rather pale. The result of laboratory analysis of andisol has 3 soil fractions which indicate that Sandy loam. Andisols texture was $57 \%$ sand fraction, $38 \%$ dust fraction and $5 \%$ clay fraction. This andisol is porous, absorbs water optimally,yet the nutrients it contains are quickly washed down then wasted or accumulated which the roots can't reach them.

The clay content kept decreasing along with duration of drying. The decrease of clay content was followed by the increase of silt and/or sand contents. Drying process caused the clay grains bounded together and formed larger particles, i.e. pseudosands and pseudosilts. In some soil samples, the drying decreased silt content, followed by the increasing sand content. This indicated that pseudosand was formed not only from clay particles, but also from the silt particles (Rahayu, 2015).

When allophanic Andisols are air-dried, their colloidal fraction irreversibly aggregates and the sand-sized fraction increases and clay-sized fraction decreases. Surface soils may experience drying under natural conditions. Therefore, the dispersion method is often ineffective for determining the clay content of surface soils that experienced natural drying. Instead, the inorganic non-crystalline materials content can be calculated using Alo and Feo contents. Other irreversible changes with air-drying are decreased liquid limit and plastic limit, water retention, and so on (Shoji et al., 1993).

Andisol in Tawangmangu area is at an altitude of $\pm 1000 \mathrm{~m}$ above sea level, at this altitude the land potential is maximum because it is still at the starting place or its origin, when the initial groundwater observation qualitatively measured soil $\mathrm{pH}$ obtained 6.6 and moisture of 7-8 ( $\mathrm{pH}$ gauge and soil moisture). Andisol is taken with the depth of $25 \mathrm{~cm}$ of precision size done with the meter. The soil that has been taken then brought to the lowland area of the city of Yogyakarta with an altitude of 133 MASL with a temperature of $39-41{ }^{\circ} \mathrm{C}$ (greenhouse temperature) with Latitude -7.775474 Longitude 110.381391 (Yogyakarta City) is a strong predicted that causing degradation of soil quality andisol to be studied.

Vertisol is a high clay-black soil, spread over arid, semiarid and tropical areas. Vertisol in the village of Pleyen, Gunungkidul district is a high clays Vertisol and difficult to be processed. Montmorillonite clay minerals (Smectite family, clay 2:1 or $10 \AA$ ) are high wrinkles because isomorphic substitution is present on the octahedral sheet dominates the vertisol. Montmorillonite expands in wet condition, so that during the rainy season the soil becomes impermeable/ muddy and very muddy with the consistency of very sticky and very clay. In contrast, in the dry season, the consistency of the soil is very firm (when moist) and extraordinarily hard (when dry) and at the same time forming cracks - crack due to the shrinking nature and forming flower structures of the cabbage) on the soil surface (Fanning and Fanning, 1989; Buol et al., 2003 cit. Sunarminto, 2008).

Vertisol which exists in Playen village has the color of darkish black then the most dominant clay fraction of $71 \%$ followed by $8 \%$ dust fraction and $21 \%$ sand with soil texture is Clay. Bulk density 1.36 
with $1.93 \%$ organic material in accordance with Ma'as statement (1996) that organic matter greatly affect the value of soil bulk density, the higher the organic matter content of a soil, the bulk density will be lower. According to Hanafiah (2014) non-porous soil (dominated by clay fractions) the soil will be more difficult to rootto penetrate, as well it will be more difficult for the water and air to circulate (drainage and aeration are worse with less water and air available). Yet, the water is not easily lost from the soil.

From each treatment of soil type differences in this experiment, Vertisol gave maximum yield on each experimental parameter, alfisol gave moderate yield and the lowest was andisol. In Vertisol, this can be attributed to the Montmorillonite 2:1 that does not affect the growth rate of plants that can interfere with the stevia roots and disconnectedits due to the expanding and shrinking habits or the drought stress that makes the plants wither. With the addition of organic fertilizer, the soil becomes more friable and the nutrients can easily be absorbed by the plant.

Andisol in this study gives the lowest yield, rather than vertisol or alfisol as it is allegedly caused by the physical state of the soil that has changed as andisol lies in the highland with high humidity. With the treatment of organic fertilizer and the same dosage as other soil types, fertilization does not really give significant effect that can improve the physical condition of the soil. As an example, daily watering of $250 \mathrm{ml} /$ pot can only last for 2-4 hours after watering, the water quickly evaporates due to the high greenhouse temperature conditions and the large number of macro pores in andisol due to its predominantly sandy texture makes the water quickly wasted under the pots and the possibility of nutrient losses that are not available to plants.

The difference in the type of fertilizer is very influential in this study. It can be seen in the ratio of $\mathrm{C} / \mathrm{N}$ which states the difference is very far between organic fertilizer from plant compost, animal manure, and the original fertilizer only from animals without additional mixes. Organic ingredients that have high $\mathrm{C} / \mathrm{N}$ mean that they are still raw. Immature compost (high $\mathrm{C} / \mathrm{N}$ ) is considered detrimental if it is given directly into the soil. Thus, the organic material will be decomposed by microbes to obtain energy. In this matter, a high microbial population also requires plant nutrients for plants and breeding. Nutrients that should be used by plants are used by microbes. In other words, microbes compete with plants to reduce existing nutrients (Rosmarkam, 2014).
The $\mathrm{C} / \mathrm{N}$ ratio affects the state of nutrients with lower means the better or more availability for the plants. In this study, it is not in accordance with the material as described above, this is of course there is a reason that the quality of compost or food of livestock used for the sample greatly affects the nutrient content that will be produced. As Joetono cit. Rosmarkam (2014) argues that the composition of nutrient manure is very varied depending on the type and type of livestock. The value of manure is influenced by: 1) the food of the animal concerned, 2) the function of the animal as a job assistant or the meat is needed, 3) type or type of animal, and 4) the number and type of material used as a cage base.

Analysis of variance for leaves yield of stevia showed that the soil type vertisol with a compost fertilizer with a dose of $12 \mathrm{~g} /$ pot has been able to meet the needs of plants to grow leaves and give more leaves than the treatment of soil types and other types of fertilizers. Meanwhile, in andisol added by manure that mixture with dose of $24 \mathrm{~g} /$ pot produced the lowest result in stevia leaf (Table 3)

Based on the results, analysis of variance for the number of clumps of stevia showed that vertisol added by manure mixture in a dose of $12 \mathrm{~g} /$ pot gave the largest number of clumps. Meanwhile, andisol added by manure mixture in dose of $24 \mathrm{~g} /$ pot gave the lowest yield (Table 4).

Based on the results, analysis of variance for the wet weight of the stevia yields showed that vertisol and the application of compost fertilizer of fertilizer $24 \mathrm{~g} /$ pot gave the most severe wet weight result. Meanwhile, in the type of soil andisol and dung manure $24 \mathrm{~g} /$ pot gave the lowest yield of wet weight of plant (Table 5).

The soil type of vertisol and the application of compost fertilizer $36 \mathrm{~g} /$ pot fertilizer gave the result of the most severe dry weight. Meanwhile, in the type of andisol and manure $24 \mathrm{~g}$ /pot gave the lowest dry weight of the plants (Table 6).

In this study, vertisol gave the best results in all parameters. According to the results of laboratory analysis of soil vertisol, the soil is inexplicably better compared to other types of soil. It can also be associated with agronomic observation results on stevia plant about the number of leaves. Nutrient elements that greatly affect the results of stevia leaves are Nitrogen (N) nutrients. This is consistent with the statement of Hanafiah (2014), the Nitrogen element mostly needed by plants as a component of production, except for plants whose production is aqueous fruit or tubers/roots. The soil properties of vertisol affect the 
Table 3. Effect of soil type, type of organic fertilizer and fertilizer dosage to the leaves yields (amount) of stevia

\begin{tabular}{lccccc}
\hline \multirow{2}{*}{ Fertilizers } & \multirow{2}{*}{ Dosage } & \multicolumn{3}{c}{ Soil Types } & \multirow{2}{*}{ Average } \\
\cline { 3 - 5 } Compost & $12 \mathrm{~g} / \mathrm{pot}$ & $494.9 \mathrm{cdef}$ & $215.7 \mathrm{f}$ & $2411.1 \mathrm{a}$ & 1040.57 \\
& $24 \mathrm{~g} / \mathrm{pot}$ & $442.3 \mathrm{def}$ & $373.7 \mathrm{def}$ & $2263.3 \mathrm{a}$ & 1026.43 \\
& $36 \mathrm{~g} / \mathrm{pot}$ & $422.7 \mathrm{def}$ & $336.0 \mathrm{ef}$ & $1928.7 \mathrm{ab}$ & 895.80 \\
& $12 \mathrm{~g} / \mathrm{pot}$ & $784.6 \mathrm{cde}$ & $316.3 \mathrm{ef}$ & $1195.3 \mathrm{bc}$ & 765.40 \\
Manure & $24 \mathrm{~g} / \mathrm{pot}$ & $788.6 \mathrm{cde}$ & $138.9 \mathrm{f}$ & $974.0 \mathrm{~cd}$ & 633.83 \\
& $36 \mathrm{~g} / \mathrm{pot}$ & $777.0 \mathrm{cde}$ & $266.3 \mathrm{ef}$ & $982.7 \mathrm{~cd}$ & 675.33 \\
Average & & 618.35 & 274.48 & 1625.85 & $(-)$ \\
\hline
\end{tabular}

Notes :The numbers followed by the same letter do not significantly different according to Duncan test at the $5 \%$ level.

Table 4. Effect of soil type, type of organic fertilizer and fertilizer dosage of the clumps yields (amount) of stevia

\begin{tabular}{llrrrr}
\hline \multirow{2}{*}{ Fertilizers } & \multirow{2}{*}{ Dosage } & \multicolumn{3}{c}{ Soil Types } & \multirow{2}{*}{ Average } \\
\cline { 3 - 5 } & & \multicolumn{1}{c}{ Alfisol } & \multicolumn{1}{c}{ Andisol } & \multicolumn{1}{l}{ Vertisol } & \\
\hline Compost & $12 \mathrm{~g} /$ pot & $15.67 \mathrm{abc}$ & $7.67 \mathrm{c}$ & $20.66 \mathrm{abc}$ & 14.67 \\
& $24 \mathrm{~g} /$ pot & $13.89 \mathrm{abc}$ & $18.00 \mathrm{abc}$ & $23.33 \mathrm{ab}$ & 18.41 \\
& $36 \mathrm{~g} /$ pot & $10.00 \mathrm{abc}$ & $8.33 \mathrm{bc}$ & $21.89 \mathrm{abc}$ & 13.41 \\
& $12 \mathrm{~g} /$ pot & $20.44 \mathrm{abc}$ & $13.00 \mathrm{abc}$ & $25.33 \mathrm{a}$ & 19.59 \\
Manure & $24 \mathrm{~g} /$ pot & $16.33 \mathrm{abc}$ & $6.67 \mathrm{c}$ & $16.33 \mathrm{abc}$ & 13.11 \\
& $36 \mathrm{~g} /$ pot & $9.78 \mathrm{bc}$ & $11.00 \mathrm{abc}$ & $15.00 \mathrm{abc}$ & 11.93 \\
Average & & 14.35 & 10.78 & 20.42 & $(-)$ \\
\hline
\end{tabular}

Notes :The numbers followed by the same letter do not significantly different according to Duncan test at the $\alpha=5 \%$ level.

Table 5. Effect of soil type, type of organic fertilizer and fertilizer dosage of the wet weight (g) of stevia

\begin{tabular}{llrrrr}
\hline \multirow{2}{*}{ Fertilizers } & \multirow{2}{*}{ Dosage } & \multicolumn{3}{c}{ Soil Types } & \multirow{2}{*}{ Average } \\
\cline { 3 - 5 } Compost & $12 \mathrm{~g} /$ pot & $22.38 \mathrm{~b}$ & $5.51 \mathrm{~d}$ & $37.97 \mathrm{a}$ & 21.95 \\
& $24 \mathrm{~g} /$ pot & $19.50 \mathrm{bc}$ & $22.36 \mathrm{~b}$ & $45.86 \mathrm{a}$ & 29.24 \\
& $36 \mathrm{~g} /$ pot & $27.32 \mathrm{~b}$ & $7.95 \mathrm{~d}$ & $44.42 \mathrm{a}$ & 26.56 \\
& $12 \mathrm{~g} /$ pot & $19.30 \mathrm{bc}$ & $11.07 \mathrm{~cd}$ & $40.07 \mathrm{a}$ & 23.48 \\
Manure & $24 \mathrm{~g} /$ pot & $24.14 \mathrm{~b}$ & $4.26 \mathrm{~d}$ & $41.08 \mathrm{a}$ & 23.16 \\
& $36 \mathrm{~g} /$ pot & $27.73 \mathrm{~b}$ & $11.72 \mathrm{~cd}$ & $40.94 \mathrm{a}$ & 26.80 \\
Average & & 23.40 & 10.48 & 41.72 & $(-)$ \\
\hline
\end{tabular}

Notes :The numbers followed by the same letter do not significantly different according to Duncan test at the $\alpha=5 \%$ level.

availability of water in the soil and the high binding nature of water makes it superior because water acts as a solvent and the carrier of nutrients from the rhizosphere into the roots then to the leaves. With the addition of compost fertilizer as much as $12 \mathrm{~g} /$ pot add nutrient equal to $0.367 \%$ and produce 2400 pieces of stevia leaves. Unlike andisol, although there is a treatment of manure with a dose of $24 \mathrm{~g} / \mathrm{pot}$ which can add Nitrogen nutrient by $0.516 \%$ and produce 373 leaves of stevia (most leaves), it still can not give maximum results. In the laboratory analysis of nutrients Nitrogen possessed by this soil is higher compared toVertisol but the influence of water storage that is not optimal makes it not being able tobe absorbed by the roots optimally due to the decrease in quality due to the movement of the soil from the place of origin. The alfisol provides a moderately poor result; Alfisols can provide better water than andisol so that the nutrients absorbed by the alfisol are better than andisols. 
Table 6. Effect of soil type, type of fertilizer and fertilizer dosage of the dry weight $(\mathrm{g})$ of stevia

\begin{tabular}{llrrrr}
\hline \multirow{2}{*}{ Fertilizers } & Dosage & \multicolumn{3}{c}{ Soil Types } & \multirow{2}{*}{ Average } \\
\cline { 3 - 5 } & & \multicolumn{1}{c}{ Alfisol } & Andisol & \multicolumn{1}{l}{ Vertisol } & \\
\hline Compost & $12 \mathrm{~g} /$ pot & $9.14 \mathrm{~cd}$ & $1.27 \mathrm{e}$ & $23.76 \mathrm{~b}$ & 11.39 \\
& $24 \mathrm{~g} / \mathrm{pot}$ & $8.72 \mathrm{~cd}$ & $11.00 \mathrm{c}$ & $30.03 \mathrm{ab}$ & 16.58 \\
& $36 \mathrm{~g} / \mathrm{pot}$ & $11.50 \mathrm{c}$ & $2.77 \mathrm{de}$ & $31.17 \mathrm{a}$ & 15.15 \\
& $12 \mathrm{~g} / \mathrm{pot}$ & $9.83 \mathrm{c}$ & $6.56 \mathrm{cde}$ & $26.1 \mathrm{ab}$ & 14.16 \\
Manure & $24 \mathrm{~g} /$ pot & $11.06 \mathrm{c}$ & $1.14 \mathrm{e}$ & $28.11 \mathrm{ab}$ & 13.44 \\
& $36 \mathrm{~g} /$ pot & $11.83 \mathrm{c}$ & $6.72 \mathrm{cde}$ & $26.77 \mathrm{ab}$ & 15.11 \\
Average & & 10.35 & 4.91 & 27.66 & $(-)$ \\
\hline
\end{tabular}

Notes :The numbers followed by the same letter do not significantly different according to Duncan test at the $\alpha=5 \%$ level.

In the parameters of the number of clumps, vertisol still gives the best result. In addition to nutrients above Nitrogen, other nutrients are predicted to have very important role, such as nutrients Phosphorus and Potassium. The main role of nitrogen $(\mathrm{N})$ for plants is to stimulate overall growth, especially stems, branches, and leaves. Phosphate (P) elements for plants are useful for stimulating root growth, especially root seeds and young plants. According Ma'as (1996), Phosphate rarely leached away because it will quickly react with the soil to form deposits or absorbed in the soil mineral colloids. The phosphate reaction causes these ions not in form to be absorbed by plants or leach out of the root zone. This is closely related to andisol with allofan clay minerals which are the dominant minerals in andisols are not yet saturated and still active, thus causing nutrients Phosphate given to the soil will be fixed by allofan minerals and $\mathrm{Al}, \mathrm{Fe}$ consequently the phosphate element becomes unavailable for plants (Djajadi et al., 2002).

Vertisol added by manure $12 \mathrm{~g} /$ pot adds phosphate nutrient equal to $49.93 \mathrm{ppm}$ and yields 25.33 clumps, is inversely proportional to soil andisol given compost $24 \mathrm{~g} /$ pot can add phosphate 89.83 ppm to produce clump as much 18 (most number of clumps). Given the results of laboratory analysis of soil phosphate content of andisol into evidence that this soil has enough phospate nutrients on the results of agronomic observations of the number of leaves and the number of clumps is inhibited because of available phosphate nutrients but can not be absorbed. Unlike the vertisol type of the Playen region made from the parent material is a napal that contains many elements of phosphate so that phosphate continues to be available for plants. Phosphate nutrient deficiency are seen in the results of soil analysis of alfisol with only $3.73 \mathrm{ppm}$ with lower esters than andisols, but this soil can directly provide nutrients to be directly utilized by plants, inversely with the andisol that absorb it because there is allophane.

According to Ma'as (1996) the function of Potassium $(\mathrm{K})$ is to activate enzymes, carbonhydrate formation, play a role in respiration, plant physiological processes, enhance plant resistance and affect other nutrients. The potassium content in soil vertisol was

Table 7. Measuring N, P and K nutrient status available in the soil after incubation then being given organic fertilizer and NPK Phonska as the standart fertilizer.

\begin{tabular}{|c|c|c|c|c|c|c|c|c|}
\hline \multirow{2}{*}{$\begin{array}{l}\text { Type of analy- } \\
\text { sis }\end{array}$} & \multirow{2}{*}{$\begin{array}{l}\text { Dosage } \\
\text { Organic \& NPK }\end{array}$} & \multicolumn{3}{|c|}{ Compost + NPK in the soil } & \multicolumn{3}{|c|}{ Manure + NPK in the soil } & \multirow[t]{2}{*}{ Rating } \\
\hline & & Alfisol & Andisol & Vertisol & Alfisol & Andisol & Vertisol & \\
\hline \multirow{3}{*}{$\mathrm{N}(\%)$} & $12 \& 0.1 \mathrm{~g} / \mathrm{pot}$ & 0.234 & 0.516 & 0.367 & 0.2135 & 0.517 & 0.368 & Low-Medium \\
\hline & $24 \& 0.1 \mathrm{~g} / \mathrm{pot}$ & 0.237 & 0.519 & 0.370 & 0.240 & 0.521 & 0.373 & Low-Medium \\
\hline & $36 \& 0.1 \mathrm{~g} / \mathrm{pot}$ & 0.241 & 0.521 & 0.373 & 0.245 & 0.525 & 0.377 & Low-Medium \\
\hline \multirow{3}{*}{$\mathrm{P}(\mathrm{ppm})$} & $12 \& 0.1 \mathrm{~g} /$ pot & 59.88 & 46.07 & 49.93 & 11.40 & 8.78 & 9.53 & High \\
\hline & $24 \& 0.1 \mathrm{~g} / \mathrm{pot}$ & 116.76 & 89.83 & 97.33 & 19.80 & 15.24 & 16.53 & High \\
\hline & $36 \& 0.1 \mathrm{~g} / \mathrm{pot}$ & 173.64 & 133.58 & 144.73 & 28.20 & 21.70 & 23.53 & High \\
\hline \multirow{3}{*}{$\mathrm{K}\left(\mathrm{cmol}(+) \mathrm{kg}^{-1}\right.$} & $12 \& 0.1 \mathrm{~g} / \mathrm{pot}$ & 1.00 & 1.35 & 1.02 & 0.87 & 1.24 & 1.05 & Low \\
\hline & $24 \& 0.1 \mathrm{~g} / \mathrm{pot}$ & 1,19 & 1.49 & 1.08 & 0.91 & 1.28 & 1.09 & Low \\
\hline & $36 \& 0.1 \mathrm{~g} /$ pot & 1.38 & 1.64 & 1.13 & 0.96 & 1.32 & 1.29 & Low \\
\hline
\end{tabular}


at least $1.07 \mathrm{cmol}^{(+)} \mathrm{kg}^{-1}$ in compost and $1.14 \mathrm{cmol}$ (+) $\mathrm{kg}^{-1}$ in manure, this was thought to be because the vertisol contained in the Playen area had 2:1 clay type. When exposed the $\mathrm{K}^{+}$ions are attracted to the negative charge on the inner surface of the clay grille, then when it dry, the bonded $\mathrm{K}$ becomes pinched so that it is bonded stronger in the lattice so it is not available to the plant. Then when it wet again, the potassium is partially bonded strongly, thus remaining unavailable, while others are available (Hanafiah, 2014). This has something to do with watering every day as much as $250 \mathrm{ml} /$ pot because it can affect the soil temprature, high soil temprature then the fewer fixed $\mathrm{K}^{-}$ions are fixed. Thus, in vertisol potassium soils are still available (although few) and can be absorbed by plants. According to Tisdale (1985), lack of potassium causes potassium production to decline, although often does not show symptoms of deficiency. This occurrence is called "hidden hunger" as it happens in the type of soil andisol with higher potassium nutrients than vertisol with a mean of $1.49 \mathrm{cmol}^{(+)} \mathrm{kg}^{-1}$ (compost fertilizer) and 0.75 cmol $(+) \mathrm{kg}^{-1}$ (manure) with a certain dose is still has not given maximum results. This has something to do with the $\mathrm{C} / \mathrm{N}$ ratio of 7.3 on the andisol which is still high because of the relatively young soil. In Nuryani et al. (1993), the organic material given to andisol has a smaller role than the original soil organic matter, hence the application of organic fertilizer in this experiment has little effect on soil andisol.

The treatment of organic fertilizer with compost fertilizer and dosage $24 \mathrm{~g} /$ pot gave the best result on each parameter, which means that dose of $24 \mathrm{~g} /$ pot is the most suitable dose in this study than the dose of fertilizer $12 \mathrm{~g} /$ pot or $36 \mathrm{~g} /$ pot. This can be predicted because the dose of $12 \mathrm{~g} / \mathrm{pot}$ is too small and the dose of $36 \mathrm{~g} / \mathrm{pot}$ is too much so that the late decomposition of organic matter by soil substances or microorganisms in the soil. Soil temperature greatly affects soil microbial activity. This activity is very limited to temperatures below $10^{\circ} \mathrm{C}$, the optimum rate of beneficial soil biota activity occurs in the $18-30{ }^{\circ} \mathrm{C}$ temperature, such as N-binding bacteria in well drained soils. Nitrification lasts optimum in the temperature around $30^{\circ} \mathrm{C}$. At temperatures above 30 ${ }^{\circ} \mathrm{C}$ more $\mathrm{K}^{-}$elements are exempted than in lower temperature, so their absorption by roots increases. At temperatures above $40^{\circ} \mathrm{C}$, microbials generally become inactive (Hanafiah, 2014). Can be predicted by the soil surface, the activity of microorganisms less, with the availability of water in the soil can decrease the soil temperature so that the activity of microorganisms is also higher. With the application of manure on stevia planting media, the growth and production of stevia better than the treatment without manure (Syukur, 1996).

Based on the results of observation on the wet weight harvest of plant stevia, vertisol with the application of compost fertilizer and dosage $24 \mathrm{~g}$ /pot gives the best results; it is suspected because of the nutrients potassium sufficient for plant stevia. Result of potassium nutrient analysis (Available K) laboratory on soil of vertisol is higher than alfisol or andisol. According to Prawiranata et al. (1986), potassium elements are present in maristemic tissues so that they influence $\mathrm{Ca}, \mathrm{Mg}, \mathrm{N}$ and $\mathrm{P}$ absorption. The function of K elements in plant metabolism is as a catalyst, a role in protein synthesis and char metabolism. This element also acts as a cell division, which directly affects the increase in plant height and number of leaves. With the increasing number of leaves, the result is directly proportional to the wet weight of the stevia plant itself.

According to Buana and Gunadi (1985) that in general to a certain extent the higher the plant, the more the number of leaves so the higher the leaf dry weight. Goenadi (1985) states the use of manure can increase plant height and leaf formation, so as to increase the dry weight of stevia plants. The result of observation on dry weight parameter of crop yield, vertisol with compost fertilizer and dosage 36 $\mathrm{g} /$ pot give best result, inversely with result of wet weight of plant stevia. This is presumably because the compost fertilizer with a dose of $36 \mathrm{~g} /$ pot can increase stevia stem diameter, thereby increasing the dry weight of the plant.

In journals written by Djajadi (2014) provide information that the growth and production of stevia is strongly influenced by pruning, fertilizing and plant populations. Pala et al. (2013) in its two years study reported that the interest rate cut could increase the production of dried leaves by 1.36 ton $\mathrm{ha}^{-1}$ (2010) and 1.59 tons ha ${ }^{-1}(2011)$ or 13 and $17 \%$ respectively compared to crop production which is not trimmed. Spraying of liquid fertilizer $\mathrm{KNO}_{3}$ with a concentration of $5 \mathrm{gl}^{-1}$ is also reported to increase production by 26 and 17\% respectively in 2010 and 2011 compared to those only water sprayed (Pala et al., 2013). The optimal population or plant density for stevia plants is $8-10$ plants $\mathrm{m}^{-2}$ Sefraty et al. (2013) reported that at a density of 10 plants $\mathrm{m}^{-2}$ can be produced as much as $0.30 \mathrm{~kg}$ of dry leaves $\mathrm{m}^{-2}$ and $30.9 \mathrm{~g}$ steviosida $\mathrm{m}^{-2}$. Therefore, in one hectare can be produced as much as 1000$2000 \mathrm{~kg}$ of dry leaves containing $60-70 \mathrm{~kg}$ steviosida. The productivity is much lower than that of 
sugarcane productivity, which is 95 ton $\mathrm{ha}^{-1}$ in rice field and 75 ton ha-1 on moor (Indrawanto et al., 2010). However, because stevioside has a sweetness level of 300 times than sukrose, the productivity is equivalent to $21,000 \mathrm{~kg}$ of sugarcane per hectare.

In this study if in a matter of hectares, the number of plants $100,000 \mathrm{ha}^{-1}$ with a spacing of $15 \mathrm{~cm} \mathrm{x} 15$ $\mathrm{cm}$, stevia dry weight production on vertisol reached $2,766 \mathrm{~kg} \mathrm{ha}^{-1}$ or 2.7 ton ha-1, alfisol reached 1 ton haand andisol only $491 \mathrm{~kg} \mathrm{ha}^{-1}$. However, in the content of stevioside on alfisol gives the best result that is $6.21 \%$ different with vertisol land which only $3.74 \%$ and andisol $4.51 \%$. Referring to the results of the research of Pala et al. (2013), the production of dried leaves reaches 1.59 tons $\mathrm{ha}^{-1}$, the result of which is that the alfisol can be the closest reference and gives the best stevioside content in the lowlands than the soil type vertisol and andisol. Although the results of leaves on vertisol are better, the level of stevioside sugar content does not meet the need for production. In alfisol, this soil treatment is close to the result with Atmoko (2001) research on alfisol treatment resulted stevioside with yield of $7.91 \%$.

\section{CONCLUSIONS}

Vertisol given by compost fertilizer with dose $12 \mathrm{~g} /$ pot and $24 \mathrm{~g} /$ pot gave best result on leaf number, number of clump and plant length. Vertisol with best compost fertilizer treatment in wet weight and dry weight, but on the result of stevioside production of alfisol better than vertisol. Andisol gave the lowest yield on each treatment parameter, followed by the second result of alfisol and first for soil vertisol with various organic fertilizer and dosage treatments. Production of stevioside content in alfisol gave the best result compared to the results of andisol and vertisol on various types of fertilizers and dosages.

\section{REFERENCES}

Atmoko, M.A.B. 2001. Pemberian Gambut RawaPening pada Tanah Latosol untuk Meningkatkan Pertumbuhan dan Kandungan Gula pada Tanaman Stevia (Stevia rebaudiana Bertoni M.) [Essay]. Bogor:Fakultas Matematika dan IlmuPengetahuan Alam, Institut Pertanian Bogor.

Buana, L dan DH.Goenadi, 1985. StudiT entang Korelasi Antara Pertumbuhan dan Produksi Tanaman Stevia, Menara Perkebunan 53(3): 68-71

Buol, S.W., Southhard, R.J., Graham. R.C. dan Mc Daniel, P.A. (2003). Soil Genesis and Classification. The Iowa State Univ. Press,
Ames.

Djajadi, M. Sholeh, dan N. Sudibyo. 2002. Pengaruh PupukOrganik dan Anorganik ZA dan SP 36 Terhadap Hasil dan Mutu Tembakau Temanggung Pada Tanah Andisols. Jurnal Littri. Vol.8. No.1.

Djajadi. 2014. Pengembangan Tanaman pemanis Stevia rebaudiana (Bertoni) di Indonesia. Perspektif Vol. 13 No. 1. $25-33$.

Fanning, D.S. dan Fanning M.C.B (1989). Soil Morphology, Genesis and Classification. John Wiley. J Sons, Singapore.

Goenadi, D. H.1994. Peluang aplikasi mikroba dalam menunjang pengelolaan tanah perkebunan. Bioteknologi Perkebunan 1 : 17-22.

Goenadi DH. 1985. Pengaruhpupukkandang, pupuk NPK, dan pupukorganikcairterhadap stevia. Menara Perkebunan 53:29-34.

Hanafiah, K. A.2014. Dasar-Dasar Ilmu Tanah. Rajawali Pers. Jakarta

Hardjowigeno S. 2003. Ilmu Tanah. Jakarta :Akademika : Pressindo.

Lemus-Mondaca, R.; A. Vega-Galves, L. Zura-Bravo, K. Ah-Hen. 2012. Stevia rebaudiana Bertoni, source of a high-potency natural sweetener: A comprehensive review on biochemical, nutrional and functional aspects. Food Chemistry 132: 1121-1132.

Ma’as, A. 1996. Ilmu Tanah dan Pupuk. Handout. Akademi Penyuluh Pertanian (APP) Yogyakarta. Yogyakarta.

Nursyamsi, D, S.M. Nanan, Sutisniand IPG. Widjaja Adhi. 1996. Erapan P dan Kebutuhan Pupuk P UntukTanamanPangan pada Tanah-Tanah Asam. Pusat Penelitian Tanah dan Agroklimat Bogor. inJurnal Tanah Tropika. Tahun II No.2.

Nuryani H.U., T. Notohadiningrat, R. Sutantoand B. Radjagukguk. 1993. FaktorJerapan dan Pelepasanfosfat di tanah Andosol dan Latosol. Jurnal BPPS UGM: 6(4b).

Pala, P.K., R. Prasad, V. Pathaniaa. 2013. Effect of decapitation and nutrient applications on shoot branching, yield, and accumulation of secondary metabolites in leaves of Stevia rebaudiana Bertoni. Journal of Plant Physiology. 170:1526-1535.

Prawiranata, H., S. Harran and P. Tjondronegoro. 1990. Dasar-Dasar Fisiologi Tumbuhan. Fakultas MIPA-IPB. Bogor. 339 hal.

Rahayu, A., Utami, S. R., Prijono, S. 2015. The Changes of Soil Physical and Chemical Properties of Andisols as Affected by Drying and Rewetting Processes. Journal of Degraded and Mining Lands Management. Volume 3, No. 1, pp. 439-446. 
Rina, D. 2015. ManfaatUnsur N, P, dan K BagiTanaman. Jakarta. Indonesia.

Rosmarkam, A. Yuwono, N. W. 2014. Ilmu Kesuburan Tanah. PenerbitKanisius. Yogyakarta.

Shock, C. 1982. Experimental cultivation of Rebaudi's stevia in California. University of CaliforniaDavis, Agronomy Progress Report, April pp. 122 .

Shoji, S., M. Nanzyo and R.A. Dahlgren (1993) Volcanic Ash Soils -Genesis, properties and Utilization. Developments in Soil Science 21, Elsevier, Amsterdam, pp.1-288.

Smarrt, J. 1992. Phaseolus vulgaris L. Bogor, Indonesia: Prosea Foundation.

Singh, S. And Rao, G. 2005. Stevia: The herbal sugar of 21st Century. Sugar Tech, 71:17-24
Sunarminto, B.H. Santosa. H. Daya Mengembang dan Mengerut Montmorillonit I: Pengaruh Intensitas Curah-Embun Terhadap Pengolaha Tanah Vertisol di Kecamatan Tepus dan Playen, Pegunungan SeribuWonosari-RisetLaboratorium. AGRITECH, Vol. 28, No. 1

Syukur. M. 1996. PengaruhPemberian Lumpur Buangan dan Pengolahan Limbah Sintesis Antibiotika dan Pupuk Kandang terhadap Pertumbuhan dan Produksi Stevia (Stevia rebaudiana Bertoni M.) [Essay]. Bogor :FakultasPertanian, InstitutPertanian Bogor.

Tisdale, S.L., W.L. Nelson\& J.D. Beaton. 1985. Soil Fertility and Fertilizers. MacMillan Pub. Co. New York.

Todd, J, and Glade, M. 2010. The Cultivation of Stevia, "Nature's Sweetener". Omafra. Ministry of Agriculture and Food. Ontario, Canada. 